\title{
Correction to: Diagnostic performance and clinical application of preoperative COVID-19 bedside testing with ID NOW ${ }^{\mathrm{TM}}$
}

\author{
Tonia Tauh, MD, FRCPC • Susan M. Lee, MD, MAS, FRCPC D • \\ Paula Meyler, MD, FRCPC • Michelle Mozel, MSc • Meghan McLennan, BSc, MLT • \\ Linda M. N. Hoang, MD, MSc, DTM\&H, FRCPC
}

Published online: 15 July 2021

(C) Canadian Anesthesiologists' Society 2021

\section{Correction to: Can J Anesth/J Can Anesth https://doi.org/10.1007/s12630-021-02035-w}

In this article, second column, second paragraph, line 8: specificity of $99.7 \%$ (95\% CI, 92.2 to 99.4) should read: "specificity of $99.7 \%$ (95\% CI, 92.2 to 99.9$)$ ".
Publisher's Note Springer Nature remains neutral with regard to jurisdictional claims in published maps and institutional affiliations.

The original article can be found online at https://doi.org/10.1007/ s12630-021-02035-w.

T. Tauh, MD, FRCPC · S. M. Lee, MD, MAS, FRCPC $(\bowtie)$. PaulaMeyler, MD, FRCPC $\cdot$ M. Mozel, MSc

Department of Anesthesia and Perioperative Medicine, Royal

Columbian Hospital, New Westminster, BC, Canada

e-mail: suze.lee@utoronto.ca

Department of Anesthesiology, Pharmacology \& Therapeutics,

The University of British Columbia, Vancouver, BC, Canada

M. McLennan, BSc, MLT · L. M. N. Hoang, MD, MSc, DTM\&H, FRCPC

BC Centre for Disease Control Public Health Laboratory,

Vancouver, BC, Canada

Department of Pathology \& Laboratory Medicine, The

University of British Columbia, Vancouver, BC, Canada 